\title{
Social Economic Status of Etawa (Pe) Goats Farmers in Tamansari Village, Ampelgading District, Malang Regency, Indonesia
}

\section{Sita Arum Prabawati"1, Bambang Ali Nugroho², and Siti Azizah²}

\author{
${ }^{1}$ Student of Magister Program, Socio-economics Department, Faculty of Animal Science \\ Brawijaya University, Malang, Indonesia
}
${ }^{2}$ Lecturer of Magister Program, Socio-economics Department, Faculty of Animal Science Brawijaya University, Malang, Indonesia

E-mail: sitaarumprabawati@gmail.com; bamalnug@ub.ac.id; siti.azizah@ub.ac.id

*Corresponding author details: Sita Arum Prabawati; sitaarumprabawati@gmail.com

\begin{abstract}
This research was conducted in October 2019 at Tamansari Village, Ampelgading District, Malang Regency. This study aims to describe (1) household characteristics of PE goat farmers in Tamansari Village, Ampelgading District, Malang Regency, (2) ownership status of production facilities assets, (3) ownership characteristics of PE goats include ownership status, rearing purposes, average number of ownership, the average number of sales and sales value of PE goats. This study uses a survey method. The type of data taken is primary data through interviews. The data obtained were then analyzed descriptively. The results showed that the respondents were at productive age, had a relatively low level of formal education, had a small number of family members, and were very experienced in PE goats breeding. The assets of production facilities that owned by goat farmers are barns, feed warehouses, wheelbarrows, motorcycles and handphones. The average status of livestock ownership is self-owned with the aim of raising PE goats as the main business and side business. The average ownership of PE goats in Tamansari Village was started from $14.50 \pm 3.90$ in Tamansari sub-village to $17.57 \pm 11.30$ in Tamanrejo sub-village. The average livestock sales per year was started from $5.82 \pm 6.01$ heads in Tamansari sub-village to $9.14 \pm 9.82$ heads in Tamanrejo sub-village. The average value of livestock sales received by breeders were started from IDR $1.79 \pm 0.69$ million per head in Tamansari sub-village to IDR 1.90 \pm 1.23 million per head in Tamanrejo sub-village.
\end{abstract}

Keywords: socio-economic; goat farmers; PE goat; Malang; Indonesia

\section{INTRODUCTION}

Malang Regency is an area that is suitable for use as a place for livestock business development because it has a good agro-climate. Various types of livestock are developed in Malang Regency such as cows, goats, broilers, layers and so on. In 2019 the population of beef cattle in Malang Regency was 238,282 heads, dairy cows 86,058 heads, buffaloes 983 heads, horses 519 heads, while goats amounted to 261,546 heads [1] (BPS, 2020). An interesting fact is that the goat population increased rapidly from 2018 from 34,294 to 261,546 in 2019 . This shows that there is a development of goat farming business in Malang Regency.

Ampelgading District, which is located on the slopes of Semeru Mt, is one of the leading areas for goat farming in Malang Regency. One of the prominent livestock commodities in Ampelgading District is PE goat. [2] BPS (2020) mentions that the population of PE Goats in Ampelgading District is 53,546 heads or $20.47 \%$ of the goat population in Malang Regency. Meanwhile, more than a third of the goat population in Ampelgading District is in Tamansari Village. Tamansari Village is located on the slopes of Semeru Mt., Ampelgading District, which is an isolated village with quite difficult access. The 915.20hectare village has a population of 1,604 people. However, it has abundant forage potential that allows people to raise PE goats.
Based on the description above, it can be said that the prospect of developing PE goat business is still widely open. In addition to the technical factors of livestock production, feed, and marketing, socio-economic factors also need to be considered in the strategy for developing goats in the Ampelgading District. Therefore, this study aims to determine the socio-economic conditions of PE goat farming business in Ampelgading District which include the characteristics of the breeder's household, ownership status of production facilities assets, the characteristics of PE goat ownership which is including ownership status, breeding objectives, average number of ownership, the average number of sales and sales value of PE goats.

\section{RESEARCH METHODOLOGY}

Research sites

This research was carried out in Tamansari Village, Ampelgading District, Malang Regency, East Java on October 2019. The selection of Tamansari Village as the research location was carried out by purposive sampling according to the instructions [3] Singarimbun and Effendi (1995) which based on the consideration that the largest population of PE goats was in Ampelgading District was in this village. 


\section{Research Methodology}

The research was carried out using a survey method which was divided into two stages, which consist of the pre-survey and survey stages. The pre-survey stage is carried out to see the general condition of the area, so that the research location and object can be determined as respondents. At the survey stage, primary data was collected by conducting interviews with PE goat farmers.

\section{Research Object}

The research object consisted of 43 PE goat farmers which spread over two sub-villages in Tamansari Village as research respondents. All of these respondents are active farmer in farmer's group institution.

\section{Data Collection and Analysis}

At the survey stage, it was done by collecting primary data. Primary data was obtained through interviews with the heads of households of PE goat farmers who were selected as respondents which guided by a questionnaire. The questionnaire contains several closed and openended questions [4] (Dwiastuti, 2017). The questionnaire has been designed to obtain information about the characteristics of respondents and the socio-economic aspects of PE goat farmers. The primary data were including age, education level, age and number of family members, and experience in breeding livestock. In addition, this study also reveals the status of livestock ownership, the purpose of developing livestock, the average livestock ownership, the average livestock sales per year, and the value of livestock sales. Further research data analyzed descriptively.

\section{RESULT AND DISCUSSION}

\section{Research Site Overview}

Tamansari Village, Ampelgading District, Malang Regency is a village with the majority of the population are living as breeders and breeders. Geographically, this village is located on the slopes of Semeru Mt. with a hilly topography. This village has an area of $915.20 \mathrm{Ha}$. Most of the land in this area was used as upland/garden, yard, and forest. Plantation products were dominated by sugarcane and Robusta coffee. Meanwhile, the livestock population was dominated by goats (Central Bureau of Statistics, 2020). The most common type of goat is PE (Etawa) goat. [2] BPS (2020) mentions that the population of PE Goats in Ampelgading District is 53,546 heads or $20.47 \%$ of the goat population in Malang Regency. Meanwhile, more than a third of the goat population in Ampelgading District is in Tamansari Village. Abundant forage and geographical environmental conditions strongly support the development of PE goats in this region.

On average, the PE goat breeding system in Tamansari Village has been carried out intensively, making it easier for breeders to handle and control livestock. traditional way with minimal technology. Feed and water are provided in the cage by the breeder. Cages are generally placed behind or on the side of the house in the form of a tileroofed stage. The cages are made permanent or semipermanent with wood and galvalume as raw materials. Breeders in this area keep goats for generations. [5] Hartono et.al (2006) in their research stated that the goat farming business in Tamansari Village, Ampelgading District, Malang Regency contributed $43.86 \%$ to household income. This business is also able to absorb family labor.

\section{Respondent's Household Characteristics}

The respondent's household characteristics which include age, education, number of household members, and length of raising can be seen in Table 1.

The results showed that the age of the head of the household who became the respondent varied in each Village. The average age in the two Sub-villages was almost the same, namely $49.00 \pm 12.46$ years in Tamansari Sub-villages and $48.24 \pm 12.90$ years in Tamanrejo Sub-villages. The average age in the two Sub-villages shows that the respondents of this study are included in the criteria for the population of productive age. BPS classifies productive age between 15 and 64 years, while those under 15 years and 64 years and over are classified as unproductive age. This supports the development of PE goat business in the area. This is in line with the results of research [6] Rumiyani and Hamdani (2017) which state that PE goat farmers are dominated by people of productive age. The number of family members is also relatively small, because the average farmer household only has three family members. Based on the results of the investigation of the respondents, this is due to the consideration of the distribution of resources as inheritance so that many goat farmers limit the number of their family members. This fact is different from the results of research [7] Tatipikalawan (2017) which states that goat farmers have large enough family members, which are 5-7 people to facilitate the provision of labor.

Most of the respondents only completed basic education. Only a few respondents completed their education at a higher level such as junior high school or senior high school. The low level of education of the respondents is due to the fact that school infrastructure facilities in this village are very limited. Based on observations at the research site, there are only two public elementary schools and one junior high school. If people want to take a high school education, they have to go to the center of Ampelgading District which is located quite far about $12.5 \mathrm{~km}$. In addition, the poor condition of village roads is also a factor that adds to the reluctance of the community to continue their education to a higher level. This low level of goat farmers education has an impact on limited access to new information and knowledge about various things.

However, most of the livestock business is carried out in the

TABLE 1: Breeder's household Characteristics

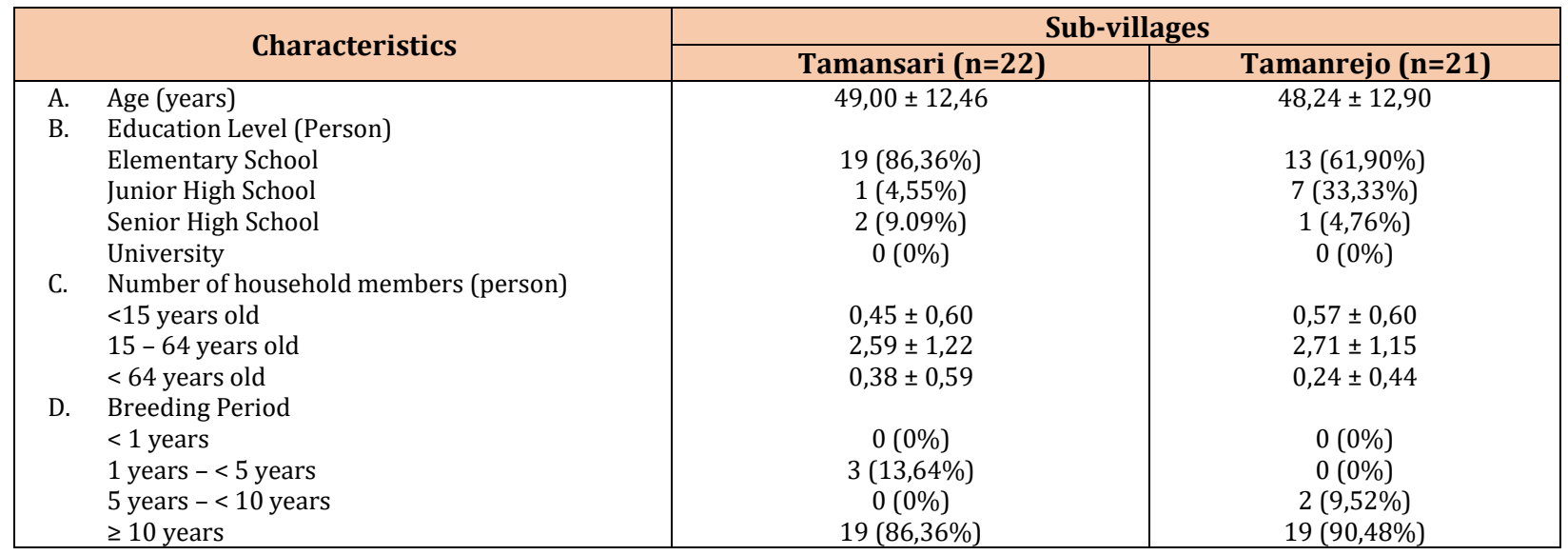

Source: Primary data process (2020) 
[8] Nugroho (2011) stated that farmers with low levels of education have an inadequate understanding of good farming practices. [9] Hidayah et.al. (2019) in his research results stated that the level of education had an effect on the adoption of technology in farming practices. The higher the level of education of farmers is expected to increase livestock productivity. An adequate level of education will be implemented to improve the management capability of their farm business.

Respondents in the study in this village are experienced in farming because most of them have been in the PE goat raising business for more than ten years. In Tamansari Sub-village as many as $86.36 \%$ of respondents, while in Tamanharjo Sub village as many as $90.48 \%$. The length of experience in raising PE goats can affect the level of success in their business. The longer the experience, the better the mastery of PE goat rearing techniques. However, the experience of raising goats makes it more difficult for farmers to accept new farming method [10] (Mulyawati et.al., 2016). This is because experienced farmers feel that their recent method was good.

\section{Ownership of livestock production facilities}

Respondent's asset ownership of supporting facilities for raising PE goats is shown in Table 2

TABLE 2: Production Facilities Assets

\begin{tabular}{|l|c|c|}
\hline \multirow{2}{*}{$\begin{array}{c}\text { Production } \\
\text { Facilities Assets } \\
\text { (per person) }\end{array}$} & \multicolumn{2}{|c|}{ Sub-village } \\
\cline { 2 - 3 } & $\begin{array}{c}\text { Tamansari } \\
\text { (n=22) }\end{array}$ & $\begin{array}{c}\text { Tamanrejo } \\
\text { (n=21) }\end{array}$ \\
\hline Barn & $22(100 \%)$ & $21(100 \%)$ \\
Feed warehouse & $1(0,47 \%)$ & $0(0 \%)$ \\
Motorcycle & $21(95,45 \%)$ & $19(90,47 \%)$ \\
Chopper & $0(0 \%)$ & $0(0 \%)$ \\
Wheelbarrow & $6(27,27 \%)$ & $11(52,38 \%)$ \\
Refrigerator & $0(0 \%)$ & $0(0 \%)$ \\
Milk container & $0(0 \%)$ & $0(0 \%)$ \\
Hand phone & $13(59,09 \%)$ & $10(45,45 \%)$ \\
\hline
\end{tabular}

Source: Primary data process (2020)

Based on the results of the study, it shown that the PE goat farmers in this location have several assets that function as business production facilities. Breeders in both areas all have barns because the rearing system used is an intensive system. Only one breeder in Tamansari village has a feed warehouse. Based on the search results, this is due to the abundant source of feed throughout the year around the area. Even in the dry season forage is still available in large quantities. Respondents took forage according to livestock needs on that day and did not store the feed.

Respondents were looking for forage for feeding the goat after cultivating the garden or field. Most of the respondents have motorcycle to carry their browsing results to their barns. Forage feed is directly given to goat without any processing so that a lot of feed were wasted.
Sometimes there were also farmers who did coarse chopping to remove the hard parts that goats don't like. However, none of the breeders owns a chopper. This is in accordance to what was stated by [11] Nisa et.al. (2019) that goat farmers are more likely to chop feed conventionally. Some respondents have wheelbarrows to facilitate the distribution of forage in the feed trough and transporting goat manure.

Although PE goats are dual-purpose livestock, the purpose of raising PE goats in this village is entirely for meat production. There is no dairy farmer, so none of the respondents have a milk storage equipment.

Respondents also never do milk storage so that none of the respondents have a refrigerator. This is different from the results of research [6] Rumiyani and Hamdani (2017) which state that most PE goat farmers have refrigerators for milk storage. The process of selling PE goats is assisted by communication tools in the form of cell phones to communicate with each other with buyers.

\section{PE goat ownership characteristics}

The results of the study show that the livestock ownership status of the respondents is dominated by self-owned livestock. This self-ownership status indicates that the respondent has adequate resources in raising livestock. Either from the provision of feed or the location of maintenance. Another form of ownership is profit sharing with other investor, and only one respondent in Tamanrejo Sub-village was paid to raise other people's goats. These two latest types of ownership status are carried out by respondents who have experience in raising goat, but do not have enough capital to manage their own farms, such as in the case of procuring PE goats breed. The purpose of raising PE goats for some respondents is as a main business while others are a side business. The characteristics of the respondent's PE goat ownership are shown in Table 3.

The average ownership of goats at the study site was 14.50 \pm 3.90 heads/person in Tamansari Sub-village and $17.57 \pm$ 11.30 heads/person in Tamanharjo village. [12] Devendra (2001) divided the ownership scale into three groups, which are 1-5 including small scale, 6-10 including medium scale, and greater than 10 including large scale. Based on the division of the scale, the number of ownership of PE goats in Tamansari Village is classified as large-scale. This condition is supported by the abundance of feed sources and environmental suitability for raising PE goats. In contrast to the results of the study [13] Sukendar et.al. (2005) which states that the scale of PE goat business in rural areas is dominated by small farms with livestock ownership of 2-5 heads, in this Tamansari village livestock ownership tends to be on a large scale. In line with the results of research [5] Hartono et.al. (2006) that the number of goat ownership in Tamansari Village varies between 8-20 heads per person.

TABLE 3: Ownership of PE Goats

\begin{tabular}{|l|c|c|}
\hline \multicolumn{1}{|c|}{ Characteristics } & \multicolumn{2}{c|}{ Sub-village } \\
\cline { 2 - 3 } & Tamansari (n=22) & Tamanrejo (n=21) \\
\hline A. Livestock Ownership Status (Person) & $16(72,73 \%)$ & $16(76,19 \%)$ \\
Self-owned & $6(27,27 \%)$ & $4(19,05 \%)$ \\
Profit sharing & $0(0 \%)$ & $1(4,76 \%)$ \\
The other party's deposit & $8(36,36 \%)$ & $13(61,90 \%)$ \\
B. Breeding purpose (Person) & $14(63,64 \%)$ & $8(38,10 \%)$ \\
Main Business & $0(0 \%)$ & $0(0 \%)$ \\
Side Business & $0(0 \%)$ & $0(0 \%)$ \\
Investment/saving & $14,50 \pm 3,90$ & $17,57 \pm 11,30$ \\
Cobby & $5,82 \pm 0,01$ & $9,14 \pm 9,82$ \\
D. Average number of holdings (Head/person) & $1,79 \pm 0,69$ & $1,90 \pm 1,23$ \\
E. Average sales of livestock (Head/person) & & \\
\hline
\end{tabular}

Source: Primary data process (2020) 
This large amount of ownership can also increase the motivation to raise livestock [14] (Nurdayati et.al., 2020). Regarding to the sale of goats, respondents in Tamansari Sub village sold about $5.82 \pm 6.01$ heads per year, while in Tamanrejo Sub village the average was about $9.14 \pm 9.82$ heads per year. Most sales are made at Eid al-Adha moment. Based on the results of the study, it was found that most of the respondents relied on middleman to sell their livestock. Respondents do not sell livestock directly because the animal market is quite far from this location. Selling to middleman is considered more efficient than selling their own livestock to the market. The average value of livestock sales per head obtained by respondents in Tamansari Sub village was about $1.79 \pm 0.69$ million rupiah, while in Tamanrejo Sub village it was about $1.90 \pm$ 1.23 million rupiah.

\section{CONCLUSSION}

Respondents were in productive age have a relatively low level of formal education, have a small number of family members, and are very experienced in raising PE goats. The assets of production facilities owned by farmers are barn, feed warehouses, wheelbarrows, motorcycles and cell phones. The average status of livestock ownership is self-owned with the aim of raising livestock as the main business and side business. The average ownership of PE goats in Tamansari Village varied from $14.50 \pm 3.90$ in Tamansari Sub village to $17.57 \pm 11.30$ in Tamanrejo Sub village. The average livestock sales per year varied from $5.82 \pm 6.01$ heads in Tamansari Sub village to $9.14 \pm 9.82$ heads in Tamanrejo Sub village. The average value of livestock sales that received by breeders starts from IDR $1.79 \pm 0.69$ million per head in Tamansari Sub village to IDR $1.90 \pm 1.23$ million per head in Tamanrejo Sub village. Further studies are needed to determine the relationship between length of goat raising experience, asset ownership, and number of livestock ownership, through the income of PE goat farmers in Ampelgading District, Malang Regency.

\section{REFERENCES}

[1] Badan Pusat Statistik Kabuaten Malang. (2020) Populasi Ternak Menurut Jenis Ternak di Kabupaten Malang (Ekor), 2017-2019.

https://malangkab.bps.go.id/statictable/2015/03/ 17/465/populasi-ternak-kecil-per-kecamatan-dikabupaten-malang-2013-2019-ekor-.html

[2] Badan Pusat Statistik Kabuaten Malang. (2020). Populasi Ternak Kecil Menurut Kecamatan di Kabupaten Malang (ekor) 2013-2019. https://malangkab.bps.go.id/statictable/2015/03/ 17/465/populasi-ternak-kecil-per-kecamatan-dikabupaten-malang-2013-2019-ekor-html

[3] Singarimbun, M. \& Efendi, S. (1995). Metode Penelitian Survey. LP3ES. Jakarta.

[4] Dwiastuti, R. (2017). Metode Penelitian Sosial Ekonomi Pertanian. UB Press, Malang.
[5] Hartono, B., Hariyono, M.B., \& Rochman, F. (2006). Usaha ternak kambing sebagai alternatif sumber pendapatan dan penyerapan tenaga kerja keluarga: studi di Desa Tamansari Kecamatan Ampelgading Kabupaten Malang Jawa Timur. J.Indon.Trop. Anim. Agric 31(2): 99-104.

[6] Rumiyani, T. \& Hamdani, M.D.I. (2017). Status sosial ekonomi peternak kambing perananakan etawa (PE) di Desa Sungai Langka, Kecamatan Gedong Tataan, Kabupaten Pesawaran, Provinsi Lampung. Jurnal Ilmiah Peternakan Terpadu Vol; 5 (2): 44-48, Juli 2017.

[7] Tatipikalawan, J.M. (2017). Karakteristik sosial ekonomi dan kendala produksi dan pemasaran ternak kambing lakor di Pulau Lakor Provinsi Maluku. Jurnal Budidaya Pertanian: Vol. 13(2): 68-73.

[8] Nugroho, E. (2011). Status sosial ekonomi peternak sapi perah di Kecamatan Poncokusumo Kabupaten Malang.

[9] Hidayah, N., Artdita, C.L., \& Lestari F.B. (2019). Pengaruh karakteristik peternak terhadap adopsi teknologi pemeliharaan pda peternak kambing peranakan ettawa di Desa Hargotirto Kabupaten Kulon Progo. Jurnal Bisnis dan Manajemen Vol.19 No.1: 1-10.

[10] Mulyawati, I.M., Mardiningsih, D., \& Satmoko, S. (2016). Pengaruh umur, pendidikan, pengalaman, dan jumlah ternak peternak kambing terhadap perilaku sapta usaha beternak kambing di Desa Wonosari Kecamatan Patebon. Agromedia Vol.34 No.1 Maret 2016: 85-90.

[11] Nisa, N.I.F, Aminuddin, A., \& Fahrudi Y.A. (2019). Aplikasi mesin pencacah pakan ternak serbaguna sebagai upaya mengurangi pengolahan pakan ternak secara konvensional. Jurnal Aplikasi Sains dan Teknologi 3 (1): 43-49.

[12] Devendra, C. (2001). Small ruminants: Imperatives for productivity enhacement improved livelihoods and rural growth. Asian-Aust J.Anim.Sci. 14 (10): 1483- 1496.

[13] Sukendar A., Duljaman M., \& Sukmawati, A. (2005). Potensi reproduksi dan distribusi dalam pengembangan kambing PE di Dea Hegarmanah Kecamatan Cicantayan Kabupaten Sukabumi Jawa Barat. Media Peternakan Vol.28 No.1: 1-7

[14] Nurdayati, Fidin, N.I., \& Supriyanto. (2020). Pengaruh karakteristik peternak terhadap motivasi beternak kambing perah. Jurnal Pengembangan Penyuluhan Pertanian Volume 17 (32), Desember 2020: 121-136 